University of Nebraska - Lincoln

DigitalCommons@University of Nebraska - Lincoln

Comparison of In Vitro Dry Matter Digestibility and Cellulase

Digestion for Deriving Near Infrared Reflectance Spectroscopy Calibration Equations Using Cool-Season Grasses

\author{
B. C. Gabrielsen \\ USDA-ARS \\ Kenneth P. Vogel \\ University of Nebraska-Lincoln, kvogel1@unl.edu \\ D. Knudsen \\ University of Nebraska-Lincoln
}

Follow this and additional works at: https://digitalcommons.unl.edu/usdaarsfacpub

Gabrielsen, B. C.; Vogel, Kenneth P.; and Knudsen, D., "Comparison of In Vitro Dry Matter Digestibility and Cellulase Digestion for Deriving Near Infrared Reflectance Spectroscopy Calibration Equations Using CoolSeason Grasses" (1988). Publications from USDA-ARS / UNL Faculty. 1886.

https://digitalcommons.unl.edu/usdaarsfacpub/1886

This Article is brought to you for free and open access by the U.S. Department of Agriculture: Agricultural Research Service, Lincoln, Nebraska at DigitalCommons@University of Nebraska - Lincoln. It has been accepted for inclusion in Publications from USDA-ARS / UNL Faculty by an authorized administrator of DigitalCommons@University of Nebraska - Lincoln. 


\title{
Comparison of In Vitro Dry Matter Digestibility and Cellulase Digestion for Deriving Near Infrared Reflectance Spectroscopy Calibration Equations Using Cool-Season Grasses
}

\author{
B. C. Gabrielsen, ${ }^{*}$ K. P. Vogel, and D. Knudsen
}

\begin{abstract}
Near infrared reflectance spectroscopy (NIRS) has recently become a potentially valuable and reliable tool for analyses of plant samples in forage-breeding programs. The success of NIRS is dependent on identification of appropriate and reliable selection criteria and development of reliable calibration. The objectives of this study were to develop and compare NIRS analysis equations for the in vitro dry matter digestibility of cool-season grasses based on either rumen fermentation (IVDMD) or cellulase-solubility (CDMD) methods and to determine if NIRS prediction equations developed from these methods would rank selected genotypes in the same order. Breeding nursery samples of smooth bromegrass (Bromus inermis Leyss.) and crested wheatgrasses [Agropyron cristatum (L.) Gaertner and Agropyron desertorum (Fisch) Schultesl were analyzed for IVDMD and CDMD to develop NIRS analysis equations. Forage samples collected at inflorescence emergence from individual genotypes in the nurseries were used to develop a rank comparison of digestibility methods. The IVDMD and CDMD laboratory values were highly correlated $(r \geq 0.95)$. Five to nine wavelengths were required to develop the NIRS analysis equations. The coefficients of determination $\left(R^{2}\right)$ from regression of laboratory values on NIRS spectra were 0.96 or higher for all equations. Validation procedures indicated excellent correlations between laboratory and NIRS estimates. Spearman rank order correlations of IVDMD- or CDMDderived NIRS digestibility values of genotypes were $\geq 0.77$ for both grasses. At least 15 or more genotypes in the top and bottom 20 were the same with either procedure for both grasses. Near infrared reflectance spectroscopy calibrations for in vitro digestibility based on either IVDMD or CDMD procedures will adequately rank genotypes in cool-season grass breeding programs in a similar order.
\end{abstract}

Additional index words: Smooth bromegrass, Bromus inermis Leyss., Crested wheatgrass, Agropyron cristatum, Agropyron desertorum.

VEAR infrared reflectance spectroscopy (NIRS) has become an accepted method of analyzing forage characteristics related to quality (Marten et al., 1985). This methodology offers considerable advantages to forage plant breeders because large numbers of samples can be analyzed in relatively short periods of time and multiple analyses can be obtained simultaneously. However, acceptable NIRS analyses are dependent upon the precision and accuracy of the laboratory methods used in developing multiple-regression predictive equations.

The in vitro dry matter digestibility (IVDMD) procedure commonly used by forage breeders to evaluate germplasm is based on a two-stage in vitro rumen fermentation technique (Tilley and Terry, 1963; Marten and Barnes, 1980). Considerable variation in IVDMD values among sample repetitions may occur when this method is used because of variation in

B.C. Gabrielsen and K.P. Vogel, USDA-ARS, Dep. of Agronomy, Univ. of Nebraska, East Campus, Lincoln, NE 68583-0915; and D. Knudsen, Dep. of Agronomy, Univ. of Nebraska, Lincoln, NE 68583. Contribution from the USDA-ARS and the Agric. Res. Div., Univ. of Nebraska, Lincoln. Paper no. 8274. *Corresponding author. Received 12 Mar. 1987.

Published in Crop Sci. 28:44-47 (1988). sources of rumen inoculum, methods of sample preparation, and variable incubation conditions (Holt et al., 1979; Horton et al., 1980; Marten and Barnes, 1980). Cellulase-solubility methods (CDMD) for estimating forage digestibility in vitro provide an alternative procedure, particularly when only relative values are required (Dowman and Collins, 1982; Bughrara and Sleper, 1986; Gabrielsen, 1986). Cellulase procedures are faster, less expensive, can be more precise than rumen fermentation methods (Marten and Barnes, 1980), and they do not require the maintenance of a fistulated animal. Marten et al. (1986) reported successful development and validation of NIRS calibration equations for standardized IVDMD and CDMD methods of analyzing in vitro digestibility of five diverse forages. The NIRS analyses of forage digestibility of grass genotypes in breeding nurseries using IVDMD- or CDMD-based calibrations have not been compared. The objectives of this study were to develop and compare NIRS analysis equations for the in vitro digestibility of three species of cool-season grasses based on either IVDMD or CDMD methods and to determine if NIRS prediction equations developed from these methods would rank selected genotypes in the same order. If the rankings are similar, then a breeder would select the same genotypes even though the absolute values predicted by the two equations might differ.

\section{MATERIALS AND METHODS}

\section{Forage Samples}

Ninety-four smooth bromegrass (Bromus inermis Leyss.) samples were collected from individual plants in a spacedplanted selection nursery of a Nebraska experimental bromegrass population (NE BI 1) and an introduction evaluation nursery during a 6-week growing period (preboot to soft dough stage of maturity) in 1985. One hundred and twenty-two crested wheatgrass samples were obtained from 'Ruff' $[$ Agropyron cristatum $(\mathrm{L}$.) Gaertner] and 'Nordan' $[A$. desertorum (Fischer ex Link) Schultes] spaced-planted nurseries during this same period. Approximately 20 randomly chosen genotypes were sampled each week in both the bromegrass and crested wheatgrass nurseries. These samples were used for NIRS calibration and verification. In addition, 50 smooth bromegrass and 50 crested wheatgrass (25 of Ruff and 25 of Nordan) samples were randomly selected at panicle or head emergence from more than 300 plants each in the NE BI 1 and crested wheatgrass nurseries, respectively. These samples were used in rank comparisons for the NIRS-IVDMD vs. NIRS-CDMD rankings. Nurseries were established at least 1 yr prior to the sampling year at the Univ. of Nebraska Agricultural Research and Development Center at Mead, NE. Plants with in the nurseries were spaced on $1.1-\mathrm{m}$ centers. Nurseries were fertilized with $112 \mathrm{~kg}$ of $\mathrm{N} / \mathrm{ha}$ in early spring. The soil type was a Sharpsburg silty clay loam (fine, montmorillonitic, mesic typic Argiudoll).

Samples were dried in paper bags at $60^{\circ} \mathrm{C}$ in a forced-draft oven and ground to pass $1-\mathrm{mm}$ screen in a Wiley mill. The 
samples were subsequently reground in a cyclone mill fitted with a $1-\mathrm{mm}$ screen to increase particle size uniformity. The ground samples were stored at room temperature in plastic vials until analyzed.

\section{Laboratory Analysis}

Estimates of forage digestibility were determined for all samples using rumen fermentation in-vitro dry matter digestibility (IVDMD) and cellulase-solubility (CDMD) procedures. The IVDMD values were obtained using the twostage method of Tilley and Terry (1963) with minor modifications $\left(\mathrm{HgCl}_{2}\right.$ and $\mathrm{Na}_{2} \mathrm{CO}_{3}$ were not added after the first step). One sample of each genotype within each grass species was incubated in a single analytical run using a mixture of rumen fluid taken from two fistulated steers one of which was maintained on a diet of alfalfa (Medicago sativa L.) and the other on corn (Zea mays L.) cobs. The average of two consecutive runs was used as the laboratory IVDMD value. Estimates of digestibility as determined by CDMD (Gabrielsen, 1986) were based upon cellulase degradation of duplicate samples that had been previously extracted in neutral detergent (Goering and Van Soest, 1970). We used a marketed fungal-enzyme preparation (Type VII cellulase', Sigma Chemical Co., St. Louis, MO). Cellulase activity was equivalent to 100 filter paper units (Mandels et al., 1976) per gram of neutral detergent residue. Variation associated with each forage digestibility procedure was monitored by inclusion of five to seven samples of an appropriate standard for each species in each analytical run.

\section{NIRS Calibration and Validation Methods}

Stratified sample sets representing the range of in vitro digestibility values obtained with each laboratory procedure were compiled for NIRS calibration. Generally, two to four samples were randomly selected within each $10 \mathrm{~g} \mathrm{~kg}^{-1}$ increment to evenly cover the range of digestibility values. Sixty smooth bromegrass and 94 crested wheatgrass samples were selected for IVDMD equation development. For CDMD equation development, we used 65 smooth bromegrass and 94 crested wheatgrass samples. Samples not included in these calibration sets were used to validate prediction equations. For smooth bromegrass, there were 34 and 29 samples available for validation for the NIRS-IVDMD and NIRS-CDMD equations, respectively. Twenty-eight crested wheatgrass samples were available for both NIRS-IVDMD and NIRSCDMD equation validation.

A Technicon InfraAlyzer ${ }^{T M} 500$ scanning monochromator ${ }^{1}$ interfaced with a Hewlett-Packard 1000 Micro 26 minicomputer ${ }^{1}$ was used to develop and validate NIRS equations. Reflectance $(\log 1 / R$, where $R=$ reflectance) was determined for all samples from 1100 to $2500 \mathrm{~nm}$ at $2-\mathrm{nm}$ intervals. The first and second derivatives of $\log 1 / \mathrm{R}$ were also determined. Laboratory values from each calibration set were regressed on the corresponding spectral data using a multiple linear regression program (InfraAlyzer ${ }^{\top M}$ Data Analysis System ${ }^{1}$, Technicon Inst. Corp., Tarrytown, NY). Initial calibration equation selection was based upon a combination of statistics resulting from the regression procedure. These statistics included a small standard error of calibration (SEC), a large coefficient of determination $\left(R^{2}\right)$, and a large $F(\geq 10)$ statistic for each selected wavelength. Final equation selection was based upon prediction results using the

\footnotetext{
'Mention of a trademark, proprietary product, or vendor does not constitute a guarantee or warranty of the product by the USDA or the Univ. of Nebraska and does not imply its approval to the exclusion of other suitable products or vendors.
}

validation samples. Statistical criteria for selecting the best prediction equations were a low standard error of analysis (SEA), high $r^{2}$ between laboratory and NIRS values, slope relating laboratory values to the NIRS values that was close to 1.0, and small bias (average deviation of NIRS analyzed values from laboratory values). Following equation selection, the calibration and validation samples were combined and the equation was refit (InfraAlyzer ${ }^{\top M}$ Data Analysis System ', Technicon Inst. Corp., Tarrytown, NY) using the same wavelengths selected previously.

The NIRS values for the IVDMD and CDMD methods were ranked for each 50 -entry set of smooth bromegrass and crested wheatgrass, and the rankings were compared using Spearman rank order correlation (SAS, 1985). In addition, the similarity in sample rankings was evaluated by comparing the forage digestibility values of the upper and lower 20 samples from each set of breeding samples.

\section{RESULTS AND DISCUSSION}

\section{Laboratory Methods}

Estimates of forage digestibility based upon IVDMD and CDMD procedures were compared by simple linear regression (Table 1). Correlations between the laboratory values were highly significant $(P<0.0001)$ for both smooth bromegrass and crested wheatgrass. Separate regressions for each grass genus provided lower residual standard deviations than when the forages were considered together. Evaluation of the smooth bromegrass check or standard samples included in each assay procedure indicated a similar amount of error within each laboratory method. Averaged over runs, the standard errors of the check samples were 3.0 and $2.9 \mathrm{~g}$ $\mathrm{kg}^{-1}$ for the IVDMD and CDMD procedures, respectively. However, values obtained for the crested wheatgrass check samples indicated that the IVDMD method was more variable (average standard errors were 8.3 and $3.5 \mathrm{~g} \mathrm{~kg}^{-1}$ for the IVDMD and CDMD procedures, respectively). The higher standard error associated with the IVDMD method for crested wheatgrass appeared to be attributable to a greater amount of error within and between duplicate analytical runs compared to that of the CDMD procedure.

Although the regression analysis indicated a high

Table 1. Relationships between rumen fermentation in vitro dry matter digestibility (IVDMD) and digestibility determined by cellulase-solubility (CDMD).

\begin{tabular}{|c|c|c|c|c|c|c|}
\hline \multirow{2}{*}{$\begin{array}{l}\text { Species and } \\
\text { digestion } \\
\text { procedure }\end{array}$} & \multirow[b]{2}{*}{ Mean } & \multirow[b]{2}{*}{ Range } & \multirow[b]{2}{*}{$\begin{array}{l}\text { Prediction } \\
\text { equation } \dagger\end{array}$} & \multirow[b]{2}{*}{ RSD $\ddagger$} & \multicolumn{2}{|c|}{ Correlation $\$$} \\
\hline & & & & & $r$ & $\begin{array}{l}\text { Spear- } \\
\text { man \% }\end{array}$ \\
\hline & & - & & 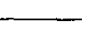 & & \\
\hline \multicolumn{7}{|c|}{ Smooth bromegrass } \\
\hline IVDMD & 638 & $485-764$ & - & -- & .- & - \\
\hline CDMD & 670 & $494-878$ & $Y=0.66 X+194$ & 23 & 0.95 & 0.96 \\
\hline \multicolumn{7}{|c|}{ Crested wheatgrass } \\
\hline IVDMD & 609 & $438-758$ & -- & -. & -- & - \\
\hline CDMD & 690 & $475-875$ & $Y=0.72 X+110$ & 24 & 0.97 & 0.93 \\
\hline \multicolumn{7}{|c|}{ Both grasses } \\
\hline IVDMD & 622 & $438-764$ & -. & -- & -- & -- \\
\hline CDMD & 682 & $475-878$ & $Y=0.68 X+155$ & 32 & 0.93 & 0.92 \\
\hline
\end{tabular}

$\dagger Y=$ IVDMD and $X=$ CDMD.

$¥ \mathrm{RSD}=$ residual standard deviation.

$\$$ All correlations are significant at $P<0.0001$

I Spearman rank order correlation coefficient (SAS, 1985). 
Table 2. The NIRS calibration statistics for smooth bromegrass and crested wheatgrass using rumen fermentation in vitro dry matter digestibility (IVDMD) and cellulase-solubility (CDMD) procedures.

\begin{tabular}{|c|c|c|c|c|c|c|}
\hline $\begin{array}{l}\text { Species and } \\
\text { digestion } \\
\text { procedure }\end{array}$ & $N$ & Mean $t$ & $\mathrm{SD} \dagger$ & SEC $\ddagger$ & $R^{2} \ddagger$ & $\begin{array}{c}\text { No. of } \\
\text { wavelengths }\end{array}$ \\
\hline \multicolumn{7}{|c|}{$\begin{array}{l}\mathrm{g} \mathrm{kg}^{-1} \\
\text { Smooth bromegrass }\end{array}$} \\
\hline $\begin{array}{l}\text { IVDMD } \\
\text { CDMD }\end{array}$ & $\begin{array}{l}60 \\
65\end{array}$ & $\begin{array}{l}625 \\
668\end{array}$ & $\begin{array}{r}80.7 \\
113.5\end{array}$ & $\begin{array}{l}17.7 \\
22.4\end{array}$ & $\begin{array}{l}0.96 \\
0.96\end{array}$ & $\begin{array}{l}5 \\
5\end{array}$ \\
\hline \multicolumn{7}{|c|}{ Crested wheatgrass } \\
\hline $\begin{array}{l}\text { IVDMD } \\
\text { CDMD }\end{array}$ & $\begin{array}{l}94 \\
94\end{array}$ & $\begin{array}{l}607 \\
684\end{array}$ & $\begin{array}{r}95.2 \\
124.1\end{array}$ & $\begin{array}{l}16.4 \\
20.8\end{array}$ & $\begin{array}{l}0.97 \\
0.97\end{array}$ & $\begin{array}{l}9 \\
8\end{array}$ \\
\hline
\end{tabular}

$\uparrow$ Mean and standard deviation (SD) of calibration sample set.

¥ Standard error of calibration (SEC) and coefficient of multiple determination $\left(R^{2}\right)$ from the least squares regression of laboratory values on the NIRS spectra.

correlation between the laboratory methods, the CDMD values, in general, were higher than the IVDMD values. This contrasted with earlier studies (Jones and Hayward, 1975; McQueen and Van Soest, 1975) which reported lower amounts of dry matter solubilized by cellulases. However, more recent studies (Roughan and Holland, 1977; Bughrara and Sleper, 1986) have demonstrated that highly active cellulase preparations solubilize greater amounts of forage than does rumen fluid. These recent observations were verified in the present study. Also it was noted that these differences were greater among the higher-quality forage samples.

Spearman rank order correlations between the IVDMD and CDMD values indicated that similar sample rankings were obtained by the two laboratory methods (Table 1). This was true even though absolute dry matter digestibility estimates were different. These results agree with previous studies (Jones and Hayward, 1975; Bughrara and Sleper, 1986; Gabrielsen, 1986) which indicated that CDMD procedures may be useful in breeding programs in which only detection of relative differences among strains is required.

\section{Near Infrared Reflectance Spectroscopy Analysis of In Vitro Digestibility}

The NIRS analysis equations were developed for each grass genus to determine in vitro digestibility via laboratory procedures. Several equations were derived using reflectance $(\log 1 / \mathrm{R})$ measurements as well as first and second derivatization of the spectral data. In all cases, the first derivative transformation produced the most acceptable equations. Calibration statistics associated with the selected equations are presented in Table 2. Five to nine wavelengths were required to produce the best equations for analysis of these forage grasses. The higher number of wavelengths necessary for the crested wheatgrass prediction equations may be due, in part, to a greater diversity in chemical composition associated with this entry since these forage samples were from two Agropyron spp. The coefficient of determination $\left(R^{2}\right)$ between laboratory values and NIRS spectra was 0.96 or greater for each method within each grass genus. Although the standard errors of calibration (SEC) were acceptable using either laboratory method, the SEC values were consistently lower for the IVDMD equations. This result was unexpected
Table 3. Validation data for the NIRS forage digestibility analysis equations.

\begin{tabular}{|c|c|c|c|c|c|c|c|c|c|}
\hline \multirow{2}{*}{$\begin{array}{l}\text { Species and } \\
\text { digestion } \\
\text { procedure }\end{array}$} & \multirow[b]{2}{*}{$\mathbf{N}$} & \multicolumn{2}{|c|}{ Mean $\dagger$} & \multicolumn{2}{|c|}{ SD $\dagger$} & \multirow[b]{2}{*}{ SEA } & \multirow[b]{2}{*}{ Bias\& } & \multirow[b]{2}{*}{$r^{2 q}$} & \multirow[b]{2}{*}{ Slope 9} \\
\hline & & Lab & NIR & Lab & NIR & & & & \\
\hline \multicolumn{10}{|c|}{$\longrightarrow \mathrm{g} \mathrm{kg}^{-1} \longrightarrow$} \\
\hline \multicolumn{10}{|c|}{ Smooth bromegrass } \\
\hline IVDMD & 34 & 663 & 667 & 58.4 & 53.8 & 16.2 & -4.4 & 0.92 & 1.04 \\
\hline CDMD & 29 & 677 & 676 & 99.8 & 97.9 & 16.6 & 0.9 & 0.97 & 1.00 \\
\hline \multicolumn{10}{|c|}{ Crested wheatgrass } \\
\hline IVDMD & 28 & 615 & 618 & 91.6 & 85.9 & 16.2 & -2.9 & 0.97 & 1.05 \\
\hline CDMD & 28 & 701 & 696 & 132.8 & 133.0 & 16.9 & 5.0 & 0.98 & 0.99 \\
\hline
\end{tabular}

because the variation associated with the CDMD procedure was similar to or lower than that of the IVDMD method. Plots of the frequency distributions of laboratory estimates obtained with both procedures (data not presented) indicated a more scattered distribution of samples within the CDMD calibration set that may have contributed to the higher SEC values.

Validation data for the equations of Table 2 are presented in Table 3. The $r^{2}$ and slope values between the NIRS estimates and the laboratory values were excellent. The standard errors of analysis (SEA) for each calibration method were generally less than the SEC (Table 2) and biases for NIRS analysis using either laboratory assay were negligible.

Following equation development and verification, the calibration and validation sample sets within each laboratory method were combined and the equations were refit using the same wavelengths and transformations (Table 4). The $R^{2}$ and SEC values were similar to those reported in Table 2. Selected wavelengths for IVDMD and CDMD analysis equations within and between species were similar (within $20 \mathrm{~nm}$ ) in about one-half the cases and were widely divergent in the remaining cases. These results contrast those obtained by Marten et al. (1986) who reported a greater similarity of wavelength selection between laboratory methods. The differences in wavelength selection observed in this study are probably indicative of the divergent values obtained with each laboratory procedure. As previously noted, CDMD values were consistently higher than the IVDMD-based estimates (Table 1). Consequently, wavelength selection would be expected to vary depending upon which laboratory values (i.e., IVDMD or CDMD) were used for calibration. In contrast, the CDMD procedure utilized by Marten et al. (1986) provided values similar to those obtained using IVDMD methods (Bughrara and Sleper, 1986). Thus, wavelength selection would probably be more similar.

Correlations of NIRS analysis of digestibility based on the IVDMD and CDMD calibrations using the smooth bromegrass and crested wheatgrass breeding samples are listed in Table 5. The correlations (i.e., $r$ and Spearman rank order) between the NIRS-IVDMD and NIRS-CDMD digestibility estimates, although lower than those obtained previously using laboratory estimates (Table 1), were still acceptable. More than $75 \%$ of the genotypes that would have been selected 
Table 4. The NIRS selected wavelengths $†$ following equation redevelopment using rumen fermentation in vitro dry matter digestibility (IVDMD) and cellulase-solubility (CDMD) procedures.

\begin{tabular}{|c|c|c|c|c|c|c|c|c|c|c|c|}
\hline \multirow{2}{*}{$\begin{array}{l}\text { Species and } \\
\text { digestion } \\
\text { procedure }\end{array}$} & \multirow[b]{2}{*}{$\mathbf{N}$} & \multirow[b]{2}{*}{ Mean } & \multicolumn{9}{|c|}{ Wavelengths } \\
\hline & & & 1 & 2 & 3 & 4 & 5 & 6 & 7 & 8 & 9 \\
\hline & & $\mathbf{g ~ k g}^{-1}$ & & & & & $-\mathbf{n m}$ & & & & - - \\
\hline \multicolumn{12}{|c|}{ Smooth bromegrass } \\
\hline IVDMD & 94 & 638 & 1219 & 1699 & 2187 & 2247 & 2339 & & & & \\
\hline CDMD & 94 & 670 & 1683 & 1887 & 1903 & 2247 & 2359 & & & & \\
\hline \multicolumn{12}{|c|}{ Crested wheatgrass } \\
\hline IVDMD & 122 & 609 & 1539 & 1623 & 1679 & 1779 & 1827 & 1947 & 2207 & 2251 & 2311 \\
\hline CDMD & 122 & 688 & 1247 & 1491 & 1535 & 1665 & 1839 & 2051 & 2179 & 2327 & -- \\
\hline
\end{tabular}

† Selected wavelengths and mathematical transformations of NIRS spectra are the same as those used in the initial calibration (Table 2).

Table 5. Comparison of in vitro dry matter digestibility (IVDMD) and cellulase-solubility (CDMD) near infrared reflectance spectroscopy (NIRS) analysis of forage in vitro digestibility of smooth bromegrass and crested wheatgrass breeding samples.

\begin{tabular}{|c|c|c|c|c|c|c|c|}
\hline \multirow{2}{*}{$\begin{array}{l}\text { Species and } \\
\text { digestion } \\
\text { procedures }\end{array}$} & \multirow{2}{*}{$\mathrm{N}$} & \multirow[b]{2}{*}{ Mean } & \multirow[b]{2}{*}{ Range } & \multicolumn{2}{|c|}{ Correlation $\dagger$} & \multicolumn{2}{|c|}{$\begin{array}{l}\text { No. of genotypes } \\
\text { in common } \\
\text { between methods }\end{array}$} \\
\hline & & & & $r$ & Spearman $\ddagger$ & Upper 20 & Lower 20 \\
\hline & & 一 & $\mathrm{g} \mathrm{kg}^{-1} \longrightarrow$ & & & & \\
\hline \multicolumn{8}{|c|}{ Smooth bromegrass } \\
\hline IVDMD & 50 & 512 & $25.0454-569$ & - & - &.- & - \\
\hline CDMD & 50 & 454 & $29.4395-5370$ & 0.79 & 0.77 & 15 & 16 \\
\hline \multicolumn{8}{|c|}{ Crested wheatgrass } \\
\hline IVDMD & 50 & 491 & $28.0 \quad 408-556$ & -. & .. & -- & -- \\
\hline CDMD & 50 & 626 & $42.6517-7330$ & 0.82 & 0.79 & 16 & 15 \\
\hline
\end{tabular}

$\dagger$ All correlations are significant at $P<0.0001$.

$\ddagger$ Spearman rank order correlation coefficient (SAS, 1985).

for either high or low IVDMD were in common in the top or bottom 20 , respectively, for both digestibility methods. Since breeders are primarily interested in relative rankings and the identification of a specified percentage of plants that have high IVDMD, these results indicate that NIRS calibrations using either IVDMD or CDMD values will result in the selection of a similar set of genotypes. The range in digestibility among bromegrass and crested wheatgrass genotypes that are harvested at a similar stage of maturity often exceeds $100 \mathrm{~g} \mathrm{~kg}^{-1}$ of dry matter (Table 5). This large range in digestibility enhances the capability of NIRS predictions, based on either IVDMD or CDMD, to rank genotypes in a similar manner. The differences between the absolute forage digestibility values obtained by the two laboratory procedures are not important since only relative rankings and identification of superior genotypes are required by breeders. Although this study was conducted with smooth bromegrass and crested wheatgrass, similar results reported by Marten et al. (1986) and the strong relationship between IVDMD and CDMD values demonstrated in previous studies (Jones and Hayworth, 1975; Bughrara and Sleper, 1986; Gabrielsen, 1986) indicates that similar results could be expected for other forages in breeding programs that use NIRS methods.

The cellulase-digestion procedure used in this study (Gabrielsen, 1986) would be easier for breeders to use for both conventional laboratory and NIRS predictions of digestibility than the procedure described by Bughrara and Sleper (1986) since marketed cellulase preparations can be used and the equipment and effort required to culture the cellulolytic fungus are unnec- essary. The activity of the cellulase preparations using Gabrielsen's (1986) procedure can also be standardized between laboratory runs, which eliminates the need to adjust cellulase concentration based on a particular forage standard.

\section{ACKNOWLEDGMENT}

The authors express appreciation to M.B. Siedell, agronomy research technician, Univ. of Nebraska, for his laboratory assistance during the course of this study.

\section{REFERENCES}

1. Bughrara, S.S., and D.A. Sleper. 1986. Digestion of several temperate forage species by a prepared cellulase solution. Agron. J. 78:94-98.

2. Dowman, M.G., and F.C. Collins. 1982. The use of enzymes to predict the digestibility of animal feeds. J. Sci. Food Agric. 33:689-696.

3. Gabrielsen, B.C. 1986. Evaluation of marketed cellulases for activity and capacity to degrade forage. Agron. J. 78:838-842.

4. Goering, H.K., and P.J. Van Soest. 1970. Forage fiber analysis (apparatus, reagents, procedures, and some applications). USDAARS Agric. Handb, 379. U.S. Gov. Print. Office, Washington, DC.

5. Holt, E.C., W.C. Ellis, and G.R. Engdahl. 1979. Forage sampling factors influencing the variability of in vitro fermentation results in grass selections. Crop Sci. 19:219-222.

6. Horton, G.M.J., D.A. Christensen, and G.M. Steacy. 1980. In vitro fermentation of forages with inoculum from cattle and sheep fed different diets. Agron. J. 72:601-605.

7. Jones, D.I.H., and M.V. Hayward. 1975. The effect of pepsin pretreatment of herbage on the prediction of dry matter digestibility from solubility in fungal cellulase solutions. J. Sci. Food Agric. 26:711-718.

8. Mandels, M., R. Andreotti, and C. Roche. 1976. Measurement of saccharifying cellulase. p. 21-33. In E.L. Gaden et al. (ed.) Enzymatic conversion of cellulosic materials: Technology and applications. John Wiley and Sons, New York.

9. Marten, G.C., and R.F Barnes. 1980. Prediction of energy digestibility of forages with in vitro rumen fermentation and fungal enzyme systems. p. 61-71. In W.G. Pigden et al. (ed.) Standardization of analytical methodology for feeds. International Development Research Centre, Ottawa.

10. - - J.L. Halgerson, and D.A. Sleper. 1986. NIRS analysis of rumen and cellulase forage digestion. Agron. Abstr. ASA, Madison, WI, p. 142.

11. _-_ J.S. Shenk, and F.E. Barton 11 (ed.) 1985. Near infrared reflectance spectroscopy (NIRS): Analysis of forage quality. USDA Agric. Handb. 643.

12. McQueen, R., and P.J. Van Soest. 1975. Fungal cellulase and hemicellulase prediction of forage digestibility. J. Dairy Sci. 58:1482-1490.

13. Roughan, P.G., and R. Holland. 1977. Predicting in vivo digestibilities of herbages by exhaustive enzymatic hydrolysis of cell walls. J. Sci. Food Agric. 28:1057-1064.

14. SAS Institute Incorporated. 1985. SAS user's guide: Statistics. SAS Inst. Inc., Cary, NC.

15. Tilley, J.M.A., and R.A. Terry. 1963. A two stage technique for in vitro digestion of forage crops. J. Br. Grassl. Soc. 18:104111 . 